\title{
THE RELATIONSHIP BETWEEN SOCIAL STATUS AND REPRODUCTIVE ACTIVITY IN MALE IMPALA, AEPYCEROS MELAMPUS
}

\author{
P. S. BRAMLEY* AND W. B. NEAVES \\ Departments of Animal Physiology and Anatomy, University of Nairobi, \\ P.O. Box 30197, Nairobi, Kenya
}

(Received 28th August 1971, accepted 13th November 1971)

\begin{abstract}
Summary. The reproductive activity of territorial and bachelor impala was compared. Mean bulbourethral gland weights and plasma testosterone levels were significantly higher in territorial males and were approximately twice that observed in bachelor males. The other parameters measured were similar in both social classes. The high testosterone levels in territorial males were probably a result of their territorial status and consequent sexual activity rather than a cause of it.
\end{abstract}

\section{INTRODUCTION}

Studies of the behaviour of many species of mammals and birds have shown that social status is an important factor in determining whether an individual breeds and, if so, how successfully. Wild populations of animals are frequently divided into territory-holding individuals, which usually breed successfully, and non-territorial individuals, which generally breed unsuccessfully or not at all (Watson \& Moss, 1970). There seems to be a positive correlation between social status and reproductive activity in many of the vertebrates which have so far been studied. Information regarding the relationship of sex hormones to social status and sexual behaviour is conflicting. Studies on the male red grouse, Lagopus lagopus, have shown that aggression (and hence, social status) and sexual activity are both controlled by androgens (Watson, 1970). On the other hand, testosterone implants in Uganda kob, Adenota kob, and roe deer, Capreolus capreolus, did not change their behaviour (Leuthold, 1966; Bramley, 1970), but a testosterone implant in a castrated male red deer, Cervus elaphus, resulted in rutting behaviour and a rise in the male hierarchy (Lincoln, Youngson \& Short, 1970). A relationship of sex hormones to sexual behaviour is suggested by evidence demonstrating that copulation and even sexual stimulation, such as the sight of a potential mate, can lead to elevated circulating levels of testosterone (Haltmeyer \& Eik-Neis, 1969; Katongole, Naftolin \& Short, 1971).

In the following study of male impala, Aepyceros melampus, we have compared various indicators of reproductive activity in two distinct groups, territorial males and bachelor males (Leuthold, 1970). In addition, we have compared

* Present address: The Grassland Research Institute, Hurley, Maidenhead, Berkshire. 
plasma testosterone levels in the two groups in an effort to detect if any relationship exists between this hormone and social status or sexual behaviour.

\section{MATERIALS AND METHODS}

Between April 1970 and March 1971, twenty-two male impala were selectively shot at monthly intervals on a ranch near Lake Elmenteita in the Rift Valley in Central Kenya. Eleven of these were territorial males and eleven were bachelor males. Only single males associating with herds of females were classified as territorial. Bachelor males were shot when in bachelor herds, care being taken not to select immature males.

Blood from the jugular or iliac vein was collected in plastic bottles and put on ice in a vacuum flask. On return to the laboratory, the blood samples were centrifuged and the plasma collected and stored at $-20^{\circ} \mathrm{C}$. Within 2 weeks of collection, plasma samples were sent by express air to Searle Scientific Services, High Wycombe, England, where testosterone assays were performed using a competitive protein-binding technique following purification by paper chromatography. Testosterone assays were performed to a precision of $\pm 10 \%$, and no differences could be detected in plasma testosterone levels measured in the blood obtained from jugular and iliac veins of the same animal. A trace amount of $\left[1,2-{ }^{3} \mathrm{H}\right]$ testosterone was equilibrated with each specimen of plasma to monitor the testosterone recovery throughout the assay and to correct for procedural losses in the final calculation.

Paired testes (without epididymides) were weighed within $10 \mathrm{~min}$ of death at an accuracy of $\pm 1 \mathrm{~g}$, using a portable spring balance. One testis was then fixed for electron microscopy while the other was fixed in $10 \%$ neutral formol saline for light microscopy. The mean diameter of the seminiferous tubules was measured at an accuracy of $\pm 3 \mu \mathrm{m}$ using an ocular micrometer on paraffinwax-embedded sections of formol-fixed testes. Fifty cross-sectional diameters of seminiferous tubules per testis were measured to ensure that the observed mean was within $5 \%$ of the true mean with a probability of $95 \%$.

Intact bulbourethral glands and seminal vesicles were removed from the animals within $20 \mathrm{~min}$ of death and were placed in polythene bags on ice. On return to the laboratory, these organs were weighed on a microbalance at an accuracy of $\pm 0.02 \mathrm{~g}$ within $24 \mathrm{hr}$ of the death of the animal.

Before cleaning, impala were weighed on a spring balance at an accuracy of $\pm 0.5 \mathrm{~kg}$.

\section{RESULTS}

The mean values for the weight of the testes and the weight of the seminal vesicles were similar in the two social groups, as were the mean seminiferous tubule diameters (Table 1). However, the mean values for bulbourethral gland weight and plasma testosterone level were significantly higher in territorial than in bachelor males $(P<0.01)$. Bulbourethral gland weight and plasma testosterone level in territorial impala tended to be approximately twice that observed in bachelor impala (Table 1).

The relationship between body weight and reproductive organ weights in the 
two social groups showed a significant positive correlation $(P<0.01)$ between body weight and testis weight, and between body weight and bulbourethral gland weight. The relationship between body weight and seminal vesicle weight was significant in bachelor males only (Table 2).

Histological examination of the testes showed active spermatogenesis in both social groups. No obvious qualitative difference in the Leydig cells in the two groups has so far been observed.

TABLE 1

GOMPARISON OF BODY, TESTIS AND ACGESSORY SEX GLAND WEIGHTS, SEMINIFEROUS TUBULE DIAMETER AND PLASMA TESTOSTERONE IN TERRITORIAL AND BACHELOR IMPALA

\begin{tabular}{l|c|c|c}
\hline & Territorial males & Bachelor males & P \\
\hline Body weight $(\mathrm{kg})$ & $63.5 \pm 1.4$ & $63.5 \pm 1.9$ & N.S. \\
Paired seminal vesicle weight $(\mathrm{g})$ & $9.7 \pm 0.9$ & $8.1 \pm 0.5$ & N.S. \\
Paired bulbourethral gland weight $(\mathrm{g})$ & $14.3 \pm 0.9$ & $7.6 \pm 1.5$ & $<0.01$ \\
Paired testes weight $(\mathrm{g})$ & $89.4 \pm 3.7$ & $85.9 \pm 5.9$ & N.S. \\
Seminiferous tubule diamter $(\mu \mathrm{m})$ & $170.2 \pm 6.0$ & $162.8 \pm 3.2$ & N.S. \\
Plasma testosterone level $(\mu \mathrm{g} / 100 \mathrm{ml})$ & $1.46 \pm 0.23$ & $0.71 \pm 0.11$ & $<0.01$ \\
\hline
\end{tabular}

Values expressed as means \pm S.E.M. for eleven males in each group. N.S. $=$ not significant at the 0.05 probability level.

TABLE 2

CORRELATION GOEFFIGIENTS BETWEEN BODY WEIGHT AND SEX ORGAN WEIGHT OF TERRITORIAL AND BACHELOR IMPALA

\begin{tabular}{l|c|c}
\hline & Territorial males & \multicolumn{1}{c}{ Bachelor males } \\
\hline Body weight versus testis weight & $-0.09(P>0.4)$ & $+0.86(P<0.0002)$ \\
Body weight versus bulbourethral gland & $+0.07(P>0.4)$ & $+0.76(P<0.003)$ \\
weight & $+0.46(P>0.07)$ & $+0.71(P<0.0006)$ \\
Body weight versus seminal vesicle weight & \\
\hline
\end{tabular}

\section{DISGUSSION}

Impala have a social structure in which some males hold territories while non-territorial males form bachelor groups. The females form herds which move through this system of territories and are mated by the territorial males. These males defend their territories against both other territorial males and bachelors, while endeavouring to retain the female herds within their territories. As a result, most females are mated by territorial males (Leuthold, 1970).

Although territorial males are more sexually active than bachelor males, their testes are essentially identical to those of bachelor males. Differences in testis weight and seminiferous tubule diameter (Table 1) and in spermatogenic activity were negligible. The similarity of the testis in these two social groups suggests that testicular development may not reflect sexual activity. On the other hand, it is possible that mature males may change their social status with sufficient frequency to ensure similar testicular development regardless of 
the social class to which they belong at any one moment. However, the observations of Leuthold (1970) on impala in The Nairobi National Park tend to discount this suggestion as the territorial males remained in the same territories for an average of 17 weeks.

The relationship of plasma testosterone levels to social status in impala raises the question of the effect of this hormone on sexual behaviour. Our data show that territorial males have significantly higher plasma testosterone levels, but do not suggest a reason for this finding. Other evidence indicates that copulation can stimulate significant increases in plasma testosterone in rabbits and men (Haltmeyer \& Eik-Nes, 1969). In rabbits, plasma testosterone levels 45 min after copulation were approximately twice those measured in control animals. Katongole et al. (1971) have recently shown that sexual stimulation and ejaculation can result in elevated blood levels of LH within 6 min, while blood testosterone levels may be elevated by a factor of 3 within $40 \mathrm{~min}$ of mating.

Clearly, sexual behaviour in some male mammals can result in relatively rapid elevation of plasma testosterone levels. On the other hand, testosterone implants in intact males have not influenced sexual behaviour (Leuthold, 1966; Bramley, 1970). Hence, we think that elevated plasma testosterone levels in territorial impala are a consequence of their sexual activity rather than a cause of it.

It is remarkable that accessory sex gland development in the two social groups is so divergent. On the one hand, seminal vesicle weight is similar, while on the other hand, bulbourethral gland weight in territorial males is twice that in bachelor males. The increase in size of the seminal vesicles is caused largely by their distension with secretion (Parkes, 1966). Only territorial males associating with female herds were shot and their frequent copulations may account for the low seminal vesicle weight.

Our data on the relationship between body weight and reproductive gland weight in the two social groups show a positive correlation only in bachelor males. This may reflect the stress of territorial status in male impala. It is possible that small changes in body weight, caused by the reduced food intake and increased activity associated with territorial tenure, occur independently of changes in accessory sex organ development, thereby obscuring any correlation that may normally exist between these parameters.

\section{ACKNOWLEDGMENTS}

We are grateful to Mr Coles of Kekopey Ranch, Lake Elmenteita, for allowing us to shoot impala on his ranch and the Kenya Game Department for collecting permits; also to Mr Mangalgi for technical assistance. Professor Robertshaw kindly criticized this manuscript.

Support for this study was provided by the Dean's Committee of the University of Nairobi and by the Milton Fund of Harvard University.

\section{REFERENCES}

BRAMLEY, P. S. (1970) Territoriality and reproductive behaviour of roe deer. $\mathcal{F}$. Reprod. Fert. Suppl. 11, 43. 
Haltmeyer, G. G. \& Eik-Nes, K. B. (1969) Plasma levels of testosterone in male rabbits following copulation. F. Reprod. Fert. 19, 273.

Katongole, C. B., Naftolin, F. \& Short, R. V. (1971) Relationship between blood levels of luteinizing hormone and testosterone in bulls, and the effects of sexual stimulation. F. Endocr. 50, 457.

LEUTHOLd, W. (1966) Variations in territorial behaviour of Uganda kob, Adenota kob thomasi (Newman, 1896). Behaviour, 27, 214.

LeUthold, W. (1970) Observations on the social organization of impala (Aepyceres melampus). Z. Tierpsychol. 27, 693.

Lincoln, G. A., Youngson, R. W. \& Short, R. V. (1970) The social and sexual behaviour of the red deer stag. F. Reprod. Fert. Suppl. 11, 71.

Parkes, A. S. (1966) The internal secretions of the testis. In: Marshall's Physiology of Reproduction. Ed. A. S. Parkes. Longmans, London.

Watson, A. (1970) Territorial and reproductive behaviour of red grouse. F. Reprod. Fert. Suppl. 11, 3.

WATson, A. \& Moss, R. (1970) Spacing behaviour and aggression in relation to population limitation in vertebrates. In: Animal Populations in Relation to their Food Resources. Ed. A. Watson. Blackwell Scientific Publications, Oxford. 